\title{
Unique Geology and Climbing: A Literature Review
}

\author{
Dmitry A. Ruban ${ }^{1,2, * \mathbb{C} \text { and Vladimir A. Ermolaev }}{ }^{3}$ \\ 1 K.G. Razumovsky Moscow State University of Technologies and Management (The First Cossack \\ University), Zemlyanoy Val Street 73, Moscow 109004, Russia \\ 2 Southern Federal University, 23-ja Linija Street 43, Rostov-on-Don 344019, Russia \\ 3 Department of Commodity Science and Expertise, Plekhanov Russian University of Economics, Stremyanny \\ Lane 36, Moscow 117997, Russia; ermolaevvla@rambler.ru \\ * Correspondence: ruban-d@mail.ru
}

Received: 4 June 2020; Accepted: 2 July 2020; Published: 4 July 2020

\begin{abstract}
Geological and geomorphological heritage (geoheritage) is often found in mountain domains that also provide resources for climbing, mountaineering, bouldering, and canyoning. The relevant research has grown in the 2010s, and its main findings need systematization. The present paper reviews the available scientific articles dealing with geoheritage and climbing activities. The number of sources remains limited, and the majority of them focus on Europe. However, these sources are rather diverse thematically. A total of 11 principal topics are delineated, and these are attributed to geoconservation, geoeducation, the tourism industry, and tourism opportunities. Several methodologies for assessment of geoheritage and climbing sites are proposed. These provide important insights, but focus on particular issues and can be applied in particular situations. Critical consideration of the available literature permits the identification of several research gaps that should be addressed by future research. The analysis of the sources implies several dimensions for sustainability judgments. Finally, the importance of the world's highest peaks for the understanding of geoheritage and climbing activities is underappreciated by the reviewed works, and this deficiency should be addressed by future investigation.
\end{abstract}

Keywords: geoconservation; mountains; tourism; anthropogenic pressure; sustainable development

\section{Introduction}

Establishing the heritage value of geological and geomorphological objects contributes to understanding of natural resources, efficient planning of conservation activities, designation of protected areas, and improvement in human-environment relationships via tourism and education. The relevant ideas can be found in the fundamental works by Bentivenga et al. [1], Brilha et al. [2], Brocx and Semeniuk [3], Dowling and Newsome [4], Gordon [5], Gray [6], Henriques and Brilha [7], Henriques et al. [8], Pescatore et al. [9], Prosser [10], Prosser et al. [11], Reynard and Brilha [12], Štrba et al. [13], Thomas [14], and Wimbledon and Smith-Meyer [15]. Simultaneously, new issues, including those related to sustainability, arise together with the growth of societal awareness and exploitation of geological and geomorphological heritage (geoheritage). Particularly, some (if not many) peculiar landforms provide excellent opportunities for climbing activities, climbing sites boast exceptional visibility of rocks in cliffs, and climbing as a sport/recreation activity produces significant anthropogenic pressure on unique geological environments. Multiple relationships and feedback mechanisms exist in these cases.

Deciphering the above-mentioned issues relevant to geoheritage and climbing activities is not only interesting in a scientific sense due to the complexity of these issues, but it is also practically important. In particular, these issues are closely linked to geotourism development. Three lines of evidence in support of this statement are as follows. First, this tourism direction has become global and 
continues to grow $[4,16,17]$. Apparently, climbing activities can enrich the experience of geotourists and contribute to geoheritage accessibility. Second, geotourism requires attention to sustainability issues [7,8,18-22]. If coupled with climbing activities, it challenges sustainable development due to the above-mentioned environmental impact of humans. Third, geotourism development is strongly related to the international geopark movement [7,23-29]. Although geoheritage lies at the "core" of geoparks, functioning of the latter cannot be restricted to only geotourism and conservation procedures. These establishments should use their potential and infrastructure to allow environmentally responsible exploitation of natural resources to satisfy their visitors and to support local communities. Climbing seems to be a highly plausible option for many geoparks.

The main objective of the present paper is to provide the first literature review of the related geoheritage management and climbing activities. Two important tasks can be addressed this way. First, various fragmentary information from literature sources is summarized, assessed critically, and systematized in order to formulate the current vision of the noted issue and to identify research gaps. Undoubtedly, this can be helpful to both theoreticians and practitioners. Second, the issue of the related geoheritage and climbing activities has to be put into the context of sustainability. Although a full-scale bibliometric approach is not employed in this paper, the aim is for this predominantly qualitative study to be as comprehensive as possible in regard to "purely" scientific developments. Non-scientific materials and real co-existence of geoheritage and climbing activities are out of the focus of this paper, which is concerned with an academic literature review. It is also necessary to add that this paper is a literature review, not a subject review, i.e., the attention is given to the systematization of the already published knowledge.

\section{Basic Terms and Ideas}

\subsection{Geoheritage}

Geoheritage includes "pure" geological heritage and geomorphological heritage, i.e., the entity of unique features of the Earth's crust that can be employed for the purposes of science, education, and tourism (cf. [30]). Although unique geomorphological features constitute a special type of geological heritage [31], studies of the former have become a significant and somewhat individual research direction [32] (see also Coratza and Hoblea in [12]), and are sensible to consider with a kind of separation from pure geological heritage studies. Geoheritage has different types and forms $[11,30]$. The former refers to the general essence of unique geological phenomena, and these are geomorphological, sedimentary, igneous, metamorphic, stratigraphical, palaeontological, palaeogeographical, mineralogical, tectonic, economical, engineering, pedological, geochemical, geocryological, geothermal, cosmogenic, hydro(geo)logical, geohistorical (or geoexploration), and complex types (the latter means the co-occurrence of two and more types). The forms include (but are not limited to) natural outcrops and landforms, quarries and mines (and entire deposits), road cuttings, mineral and fossil museum collections, and geological exhibits. Geoheritage requires conservation (geoconservation), which includes a broad spectrum of activities and formal procedures, including evaluation, monitoring, maintenance (also cleaning), protection, and promotion of unique geological and geomorphological features.

Geoheritage can be understood, very broadly, as essential characteristics of the unique geological environment. In this case, it is closely related to the idea of geodiversity [2,6,33-39]. However, of special importance are localities exhibiting geoheritage that are officially designated. Two main types of such localities are geosites and geoparks. The former are relatively small objects or areas representing unique phenomena (cf. [30]). These also include geomorphosites displaying peculiar landforms and/or geomorphological processes [32,40,41] (see also Coratza and Hoblea in [12]). Geoparks are areas specially designated for geoheritage exploitation for the purposes of tourism, education, and science, as well as for their conservation [7,23-29] (see also Brilha in [12]). These can be linked to single geosites with outstanding importance, several geosites, geodiversity hotspots, and geographical/geological domains boasting a concentration of geoheritage. Many geoparks tend to join national and international 
networks, including the United Nations Educational, Scientific and Cultural Organization (UNESCO) Global Geopark network [7] and the European Geoparks network [29]. Geosites and, in particular, geoparks are the key destinations for geotourists, and actual geotourism growth $[4,5,7,13,16,17]$ has become the logical outcome of the extensive geoheritage exploration and the official designation of its manifestations.

In fact, geoheritage and geotourism are understood to have certain differences in the research community. Geoheritage can be restricted to only those unique features that are the subject of geoconservation. However, geoheritage seems to be also important as a resource for science, education, and tourism, and often its utility for these purposes creates its value and argues for the necessity of geoconservation. Such a broad, resource-based vision is preferred in this paper. Geotourism can be understood as a broad range of activities linked to the natural environment. If so, it can exploit geoheritage together with other components of the environment. A narrower understanding of geotourism restricts it to those activities that are based on unique geological and geomorphological features, that is, those linked to the geological and geomorphological environment. To avoid confusion, such a vision of geotourism is preferred in the present paper. Nonetheless, various alternate definitions of geoheritage and geotourism may be considered, and the above-stated vision is relevant to only this paper, with its specific goals.

\subsection{Climbing Activities}

Mountainous geographical domains often host many high-angle slopes ("walls") that are linked to peaks, cliffs, and river valleys. Such slopes are ideal for (almost) extreme tourism, sport, and outdoor recreation activities that are very generally known as climbing, but can be also defined using several other terms (e.g., mountaineering (=alpinism) is the main alternative term for rock climbing, but climbing is preferred provisionally as the main generic term in this paper). Millions of more or less trained visitors to mountains are involved in these activities on an annual basis (rock climbing is paired now by indoor climbing).

Rock climbing usually means "conquering" notable peaks and cliffs (at least, reaching high points), often with a preference for challenging routes and non-trivial solutions; these activities can be linked to tourism, sport, and outdoor recreation [42], and they require some physical training [43-45], risk-taking and pleasure satisfaction [46-49], and specific geographical vision [50]. Rock climbing also exerts a significant anthropogenic pressure on the environment, although the degree of this pressure depends on different parameters and conditions, and remains debatable [51-55]. Mountaineering is a slightly more general term referring to the broader spectrum of tourism, sport, and recreation activities in mountainous domains; essentially, it refers to the same activities as climbing, although emphasizing the outdoor character of these activities [42,56]. The on-line bibliographical database Scopus includes $>320$ papers mentioning rock climbing in their titles and $>380$ papers mentioning mountaineering (state as at mid-May, 2020; some of these papers deal with geoheritage, but the majority do not). In the literature, mountaineering is often treated in regard to industry and society [57-59] and places [60,61], but chiefly to personalities (physiology and emotions) [62-71]. Environmental effects are also documented [72,73]. Two other activities that are related to climbing are bouldering and canyoning. The former means short-distance, but difficult, route climbing on big boulders (megaclasts in geological terminology) or relatively small landforms (e.g., hillocks) with steep slopes. Bouldering is more a sport or outdoor recreation activity than tourism. In the literature, this activity is discussed in regard to human physiology and psychology [74-76], and the landscape context [77] and environmental effects of bouldering are also documented $[78,79]$. Bouldering sites also facilitate finding peculiar geological objects such as megaclasts [80]. Canyoning is a kind of adventure tourism in difficult-to-access river valleys (chiefly, these are canyons and gorges) [81-84]. Partly, it is based on climbing, and steep slopes constitute its main resource. Development of canyoning is also related to the issues of risk-taking and safety $[85,86]$.

Climbing activities are strongly related to sustainability. On one hand, they challenge the latter via an increase in the anthropogenic pressure on natural environments [51-55,72,73,78,79]. On the other 
hand, these contribute to sustainable development via generating additional income and jobs, planning improvement, social and political stability, etc. [87-89]. However, the role of extreme/adventure tourism in the achievement of sustainability should not be exaggerated [90-92]. Moreover, local sustainability is a factor in the development of climbing activities (e.g., [87]).

\section{Bibliographical Survey}

\subsection{Methodological Remarks}

This paper is a literature review sharing some key principles of publications of this type [93-95]. The published academic sources (chiefly articles in international journals, which are thought to be the main and most desirable research product) that deal with both geoheritage and climbing activities were collected with the on-line bibliographical database Scopus in mid-May 2020. This database includes thousands of journals (the majority of international journals and many national journals, including those published in languages other than English; abstracts of non-English sources are provided in English) from all fields of science, and it boasts a significant degree of comprehensiveness since the mid-2000s (it is also quite complete in regard to older sources). Indeed, some papers could be published in thematic volumes and reports that are not included in Scopus. However, it is practically impossible to find and to consider all of these; moreover, consideration of only some of these would make this study biased and its bibliographical basis heterogeneous. In regard to these circumstances, the present review is restricted to the literature included in Scopus, i.e., to the "mainstream" literature available to the international research community.

The literature was collected via search by the term pairs (see below) in titles, abstract, and key words of the sources. The pairs include one term related to geoheritage (geological heritage, geomorphological heritage, geoheritage, geosite, geomorphosite, geopark, geodiversity, geological conservation, geoconservation, geological tourism, and geotourism) and one word related to climbing activities (climbing, mountaineering, bouldering, and canyoning). All possible pairs were used in the literature search. The content of the collected sources was checked in order to select only those relevant to the focus of the present review, i.e., the sources dealing with geoheritage and climbing simultaneously.

The literature on geoheritage and climbing activities is not extensive (Table 1), but it is rather diverse and allows some general conclusions to be made. Importantly, a part of this literature is directly linked to the issues of sustainable development. Indeed, there may be other sources, e.g., articles in non-scientific or popular scientific editions, and more general scientific articles mentioning the relationships between geoheritage and climbing activities only briefly (occasionally or marginally). However, these sources are unimportant for the present review, which aims to consider only scientific articles paying significant attention to the noted relationships.

Table 1. Basic information on the reviewed sources (only papers dealing simultaneously with geoheritage and climbing).

\begin{tabular}{cccccc}
\hline Source & Year & Author Country & $\begin{array}{c}\text { Focus Country } \\
\text { (Region/Locality) }\end{array}$ & Activity & $\begin{array}{c}\text { Relevance to } \\
\text { Sustainability }\end{array}$ \\
\hline$[96]$ & 2016 & Italy & $\begin{array}{c}\text { Italy } \\
\text { (Dolomites) }\end{array}$ & $\begin{array}{c}\text { climbing, } \\
\text { mountaineering }\end{array}$ & Yes \\
\hline$[97]$ & 2017 & Poland & $\begin{array}{c}\text { Poland } \\
\text { (Outer Carpathians) } \\
\text { climbing, }\end{array}$ & Yes \\
\hline$[98]$ & 2019 & Indonesia & $\begin{array}{c}\text { Indonesia } \\
\text { (Bali) }\end{array}$ & climbing & Yes \\
\hline$[99]$ & 2019 & Turkey & $\begin{array}{c}\text { Turkey } \\
\text { (Tunceli Province) }\end{array}$ & mountaineering & Yes \\
\hline$[100]$ & 2018 & Poland & $\begin{array}{c}\text { Poland } \\
\text { (Sleza Landscape Park) }\end{array}$ & climbing & Yes \\
\hline
\end{tabular}


Table 1. Cont.

\begin{tabular}{|c|c|c|c|c|c|}
\hline Source & Year & Author Country & $\begin{array}{c}\text { Focus Country } \\
\text { (Region/Locality) }\end{array}$ & Activity & $\begin{array}{r}\text { Relevance to } \\
\text { Sustainability }\end{array}$ \\
\hline [101] & 2018 & Italy & $\begin{array}{c}\text { Italy } \\
\text { (Western Alps, Apennines, Sardinia) }\end{array}$ & $\begin{array}{l}\text { canyoning, } \\
\text { climbing }\end{array}$ & Yes \\
\hline [102] & 2016 & Italy & $\begin{array}{c}\text { Italy } \\
\text { (Western Alps) }\end{array}$ & $\begin{array}{l}\text { climbing, } \\
\text { mountaineering }\end{array}$ & \\
\hline [103] & 2018 & Italy & $\begin{array}{c}\text { Italy } \\
\text { (Piemonte) }\end{array}$ & climbing & \\
\hline [104] & 2014 & Italy & $\begin{array}{c}\text { Italy } \\
\text { (Western Alps) }\end{array}$ & climbing & \\
\hline [105] & 2010 & Italy & $\begin{array}{c}\text { Italy } \\
\text { (Reggio Emilia Apennines) }\end{array}$ & climbing & \\
\hline [106] & 2011 & Italy & $\begin{array}{c}\text { Italy } \\
\text { (Finalese) }\end{array}$ & climbing & Yes \\
\hline [107] & 2014 & Czechia & $\begin{array}{c}\text { Czechia } \\
\text { (Czech Paradise Geopark) }\end{array}$ & climbing & Yes \\
\hline [108] & 2018 & Indonesia & $\begin{array}{c}\text { Indonesia } \\
\text { (North Sulawesi) }\end{array}$ & climbing & Yes \\
\hline [109] & 2014 & Romania & $\begin{array}{c}\text { Romania } \\
\text { (Haghimas Mountains) }\end{array}$ & $\begin{array}{l}\text { canyoning, } \\
\text { climbing }\end{array}$ & \\
\hline [110] & 2017 & Spain & $\begin{array}{c}\text { Spain } \\
\text { (Guadarrama Range) }\end{array}$ & climbing & \\
\hline [111] & 2020 & Turkey & $\begin{array}{c}\text { Turkey } \\
\text { (Manisa Province) }\end{array}$ & mountaineering & Yes \\
\hline [112] & 2009 & USA & $\begin{array}{c}\text { USA } \\
\text { (Colorado's Rocky Mountains) }\end{array}$ & climbing & \\
\hline [113] & 2020 & Italy & $\begin{array}{c}\text { Italy } \\
\text { (Sardinia) }\end{array}$ & mountaineering & Yes \\
\hline [114] & 2019 & Croatia & $\begin{array}{c}\text { Croatia } \\
\text { (entire country) }\end{array}$ & mountaineering & Yes \\
\hline [115] & 2017 & Spain, USA & $\begin{array}{c}\text { Spain } \\
\text { (Sobrarbe Geopark) }\end{array}$ & canyoning & \\
\hline [116] & 2007 & Italy & $\begin{array}{c}\text { Italy } \\
\text { (Sardinia) }\end{array}$ & climbing & \\
\hline [117] & 2007 & Taiwan & $\begin{array}{c}\text { Taiwan } \\
\text { (northwestern Taipei) }\end{array}$ & mountaineering & \\
\hline [118] & 2014 & Portugal & $\begin{array}{l}\text { Portugal } \\
\text { (Azores) }\end{array}$ & mountaineering & Yes \\
\hline [119] & 2012 & Brazil & $\begin{array}{c}\text { Brazil } \\
\text { (Manga do Céu, Bahia) }\end{array}$ & climbing & Yes \\
\hline
\end{tabular}

Three general approaches are employed in the present review. First, the spatio-temporal patterns of the research in geoheritage and climbing activities are studied. Publishing dynamics and geographical and geological focus of the sources are examined for this purpose. Second, the content of the sources is analyzed qualitatively to synthesize the key findings and to classify the research topics, which is also important for subsequent discussion of research gaps. Third, special attention is paid to how the issues of assessment are addressed in the selected literature. The proposed methodologies are addressed critically and compared.

\subsection{Spatio-Temporal Patterns of Research}

The research in geoheritage and climbing activities has remained relatively weak, but its spatio-temporal patterns imply its persistence in the international agenda for an extended period. The first articles exploring this subject appeared in the end-2000s, and their number has increased since 
the mid-2010s (Figure 1). Most probably, this can be explained by the rise of the geoheritage studies focusing on very particular aspects of geoheritage, as well as on its application to education, tourism, well-being, etc. In other words, the rise of the reviewed research was triggered by the geoheritage interpretation of societal needs.



Figure 1. Publishing activity related to the research in geoheritage and climbing activities.

Principally, the geographical patterns of the research in geoheritage and climbing activities can be documented with two approaches, i.e., by the author countries (the countries represented by the authors of the considered sources) and by the focus countries (the countries on which the considered sources are focused). Interestingly, the author countries and the focus countries coincide in all cases, with one exception (Table 1). Generally, the research on geoheritage and climbing activities tends to concentrate in Europe (Figure 2). The most studied are the European Mediterranean countries and East European countries, and significant emphasis is placed on the Italian localities (Table 1). The sources considered for the purposes of the present study also represent the Americas and Southeast Asia, but with only very few countries. Although the geological knowledge provided in the reviewed work is heterogeneous and it would be highly challenging to summarize it, the localities considered by previous researchers (Table 1) represent very distinct geological and geomorphological domains. Nonetheless, the number of works is too small to judge this entity of the literature comprehensive or even representative in regard to the geological/geomorphological environments.

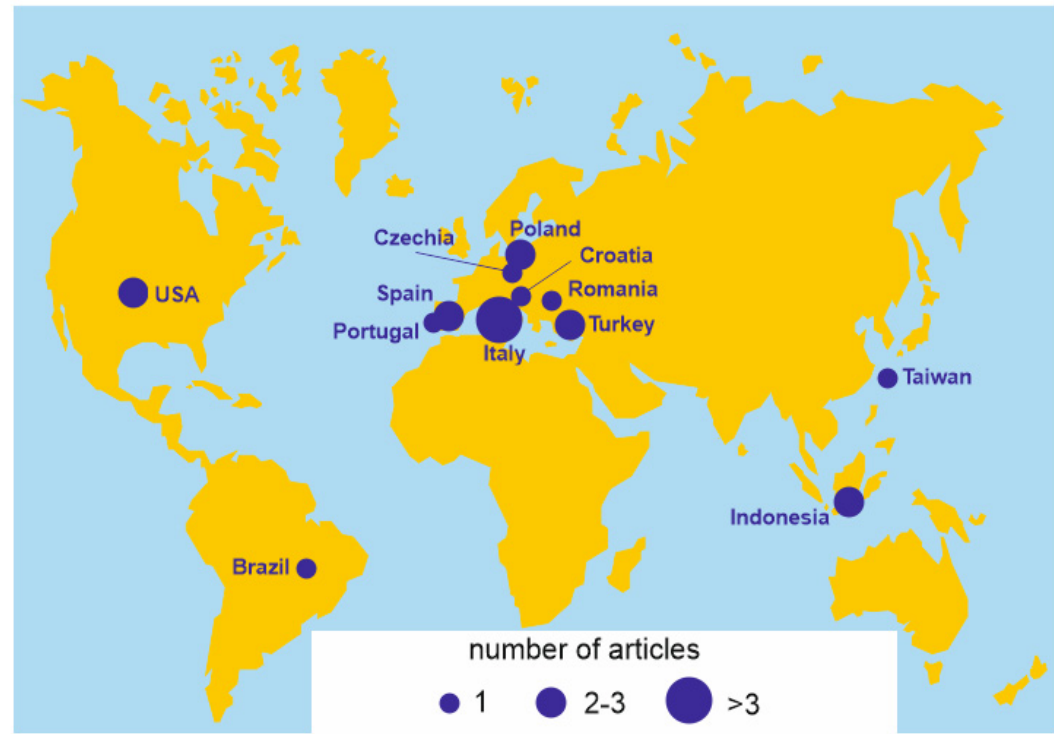

Figure 2. Geographical focus of the research in geoheritage and climbing activities. 
Of interest are also the science media in which the reviewed sources were published. One-third appeared in Geoheritage, which is the leading and high-prestige journal in geoheritage studies published by Springer and boasts a significant impact factor. The other articles were published in various geological, geographical, and environmental journals, some of which are of national status. One paper appeared in a sport journal. Importantly, no articles were published in top international journals on tourism. This generally means that the relationships of geoheritage and climbing activities are of interest chiefly to Earth scientists dealing with geoheritage. However, the reviewed research is definitely not marginal, as its outcomes are published, on one hand, in top journals such as Geoheritage and, on the other hand, in a broad spectrum of science media.

\subsection{Synthesis of Key Findings}

The content of the reviewed literature seems to be significantly diverse. Critical reading of the sources allows recognition of eleven principal topics that refer to four general contexts (Table 2). The research in geoheritage and climbing activities focuses on vulnerability of geoheritage to the anthropogenic pressure exerted by climbers, its utility for geological knowledge promotion among climbers and the broad public, and its different significance to tourism development. Importantly, more or less attention is paid to the actual relationships of geoheritage and climbing activities in all cases. The recognized topics are characterized in detail below.

Table 2. Principal topics of the reviewed literature.

\begin{tabular}{|c|c|c|}
\hline Principal Topic & General Context & Sources \\
\hline T1. Geoheritage damage by climbers & Geoconservation & {$[97,112,113]$} \\
\hline T2. Geoheritage protection from climbers & Geoconservation & {$[97,113,116]$} \\
\hline $\begin{array}{l}\text { T3. Climbing as a source of geotourist awareness } \\
\text { (education through climbing) }\end{array}$ & Geoeducation & {$[101-104,119]$} \\
\hline $\begin{array}{l}\text { T4. Geoheritage explanation to climbers } \\
\text { (special teaching of climbers) }\end{array}$ & Geoeducation & {$[96,110,111,114]$} \\
\hline T5. Diversification of activities & Tourism industry & {$[99,106]$} \\
\hline T6. Safety & Tourism industry & {$[105,116]$} \\
\hline T7. Tourist load & Tourism industry & {$[107,112]$} \\
\hline T8. Undeveloped infrastructure for climbing & Tourism industry & {$[108]$} \\
\hline T9. Resources for geotourism and climbing & Tourism opportunities & {$[98,109,115-118]$} \\
\hline T10. Climbing sites providing infrastructure & Tourism opportunities & [102] \\
\hline T11. Usage of mining sites & Tourism opportunities & [100] \\
\hline
\end{tabular}

Climbing activities may result in occasional or systemic damage of geoheritage (principal topic T1). In the case of occasional damage, climbers destroy micro-relief of unique landforms (e.g., detaching or breaking stones) or provoke snow avalanches or rockfalls that cover unique features and make them permanently or temporarily inaccessible. In the case of systemic damage, trails made by climbers, surfaces polished by their hands, and various infrastructure lead to geoheritage damage and even loss. Alexandrowicz [97] documented that climbing does not only damage micro-relief directly, but is also able to accelerate natural weathering processes. Kedrowski [112] established that the anthropogenic pressure on the environment of the regionally highest mountains is facilitated by the nearby location of a big metropolitan area, i.e., high demand for outdoor recreation activities. Marrosu and Balvis [113] found that the main danger for geoheritage results from the unbalanced planning in the areas popular among climbers when geosites become affected occasionally, i.e., without consideration of the geoheritage value in conditions of uncontrolled rise in climbing. In addition to the conclusions of these specialists, it is necessary to stress that even in the cases of zero or minimal physical damage, 
over-climbing affects the general view of geological landscapes, making them less natural, which can be termed visual damage.

If climbing contributes to the anthropogenic pressure on geoheritage, the latter should be well-protected (principal topic T2). This can be realized very differently, e.g., via improvement of planning procedures, limiting/prohibiting climbing activities, and technical solutions such as fences protecting unique features. Alexandrowicz [97] suggested that climbing on vulnerable landforms should be proclaimed unethical. Marrosu and Balvis [113] argued for improvement of planning procedures on the basis of an in-depth environmental impact assessment of climbing activities. Panizza and Mennella [114] formulated a similar idea.

Climbing is an exciting experience that attracts the attention of many people, including youth. If so, it can be used efficiently to involve the broad public into activities that extend Earth science knowledge (principal topic T3). In fact, geology is often not taught at school (except for some very elementary explanations in geographical classes), and the geological knowledge of the broad public is very limited. The relevant ideas were developed extensively by Bollati et al. [101-104]. These specialists emphasized the geosite potential of geoeducational climbing sites. They proposed routes of different difficulty, allowing comprehension of the geological and geomorphological uniqueness. The efficacy of such a geoeducation project was tested with success. Moreover, these specialists made a more general claim of natural educational laboratories that can be justified for the geosites with significant climbing potential. Russ and Nolasco [119] examined the geodiversity perception of elementary school students, and realized that this perception is often linked to climbing. If so, the latter can contribute to a better awareness of geoheritage and geological knowledge.

Climbers are motivated by such personal attitudes as risk-taking. However, they face peculiarities of the natural environment and need to understand these correctly. On one hand, this is the opportunity to improve their general knowledge. On the other hand, this understanding can help in choosing better and safer routes. Therefore, it is sensible to climbers to learn about geoheritage (principal topic T4). Aldighieri et al. [96] developed an on-line platform for gathering geoheritage-related information to be delivered to tourists, including climbers. Similarly, Nevistic and Špoljaric [114] proposed a web GIS-based tool for better awareness of mountaineers. García-Rodríguez and Fernández-Escalante [110] reported unique geological and geomorphological features from a popular climbing area in order to extend the knowledge of this area. Güney [111] found the visitors to an area with significant mountaineering often do not have sufficient knowledge of the local geoheritage, but express certain interest in this knowledge. All these results are highly important, but focus more on what to offer to climbers and how to do this. A similarly important question that is yet to be fully answered is how to stimulate the interest of climbers in geoheritage. In regard to this, the findings of Güney [111] are promising, but this is the only case study, in one particular locality. It is questionable whether climbers in other parts of the world are genuinely curious about something beyond risk-taking and admiration of panoramic views, and have the basic knowledge to comprehend geological and geomorphological information. In other words, special investigation is necessary to determine climbers' propensity to education.

Although geotourism and climbing can be linked, these are essentially different activities. Therefore, development of geotourism in an area popular among climbers, development of climbing in a geotourist destination, and development of both in an area where these activities did not previously exist, contribute to diversification of tourism (principal topic T5). Undoubtedly, the latter makes each destination more attractive to potential visitors, enriches their experience, and facilitates synergetic effects in the local tourism industry. Ates and Ates [99] argued for integration of rural tourism and geotourism in a geoheritage-rich area, and also noted that local tourism can be diversified with the rise of mountaineering. Brandolini et al. [106] focused on a karstic area with climbing as a well-established activity. They suggested that rich geoheritage co-existing with cultural heritage can facilitate promotion of sustainable tourism there. Importantly, the two noted works consider not only climbing and geoheritage resources, but put them into a broader context of tourism opportunities. 
Geotourism and climbing in mountainous domains always raises safety issues (principal topic T6). This is especially the case when "ordinary" (i.e., less-trained) geotourists enrich their experience with climbing or when climbers try to access very difficult-to-reach places exhibiting geologically-unique features (alternatively, they would choose a safer route). Borgatti and Tosatti [105] characterized a geosite that is also highly demanded by climbers. They identify slope instability as a significant factor of risk, especially due to occurring and expected rockfalls. In addition to safety recommendations, these authors proposed technical solutions to stabilize the cliff and to allow safe access. Panizza and Mennella [116] noted that geoheritage assessment should analyze risks of two kinds, i.e., risks to the geosite and risks to its visitors. The second source refers to geoconservation, but the technical solutions proposed in the first source also seem to be plausible for geosite protection from natural damage.

Although many geosites are relatively big objects, they can host only a limited number of visitors to avoid over-crowding, and the resulting poor visibility of unique features and their damage, as well as to provide the necessary safety. Tourist load (principal topic T7) was examined by Chaloupsky [107] in Europe (Czechia) and Kedrowski [112] in North America (USA). They both recognized changes in the frequency of climbing. However, they established different trends. From a historical perspective, the number of climbers can only increase or fluctuate depending on the physical space and many other factors. Nonetheless, the overcrowding of geosites that are popular among climbers is an issue for serious consideration. There is yet another issue to be addressed further. "Ordinary" geotourists may "annoy" professional climbers, whereas climbing activity can make sites less attractive to geotourists due to apparent difficulty of access. Generally, more advanced techniques of tourist crowd management should be applied to geosites and geoparks.

Geotourism requires very specific infrastructure (in the first instance necessary for the interpretation of the complex geological knowledge for unprepared visitors), and the same is true in the case of climbing activities. Therefore, infrastructure support should be the focus of the research in geoheritage and climbing (principal topic T8). This problem was addressed in the only paper by Elvien Kristian et al. [108], who demonstrated that the locally undeveloped (almost absent) infrastructure related to accommodation and site accessibility significantly limit the tourism exploitation of an important geosite to climbers and the relevant tourism contribution to the local sustainable development.

Development of geotourism and climbing requires proper resources and understanding of their value to visitors, and their documentation is an important research direction (principal topic T9). Arjana et al. [98] made an interesting observation: the preferences of professional and amateur geotourists differ significantly, and not in regard to only geoheritage, but also concerning other activities. Flaviu and Barna [109] demonstrated that climbing resources can be found in the course of geoheritage evaluation and description. Ortega-Becerril et al. [115] explained that the geological and geomorphological processes responsible for the area uniqueness and aesthetic attractiveness also make the local landscape interesting to adventure tourists, including those practicing canyoning. Panizza and Mennella [116] proposed a methodology for the description of geosites and geomorphosites in such a way to allow understanding of their utility for climbers. Pat [117] showed how geoheritage can be included in a nation-scale mountaineering trail. Queiroz et al. [118] examined the preferences of tourists visiting tropical islands with outstanding natural heritage. They registered that the natural values, including geodiversity, attract a larger number of tourists than those involved in hiking and mountaineering. This means that a significant number of potential geotourists are also potential mountaineers. Generally, the real demand for geotourism and climbing resources remains an urgent topic for future investigation, and the information available now is too local and does not permit serious generalizations.

Climbing sites, especially those equipped for people with different degrees of training, may offer appropriate infrastructure for geotourists, indicating the most suitable routes for access (principal topic T10). Such an opportunity was mentioned by Bolatti et al. [102]. Moreover, climbers may be sufficiently aware of unusual features to inform specialists in geoheritage about those features.

Geoheritage value can be boosted by, not only natural, but also artificial landforms, which can also provide opportunities for climbing (principal topic T11). Baczynska et al. [100] considered abandoned 
quarries as geoheritage objects and also as potential climbing sites. However, not all quarries are truly attractive for climbers, and quarry attractiveness depends on different parameters, including aesthetic properties.

\subsection{Assessment Methodologies}

The research in geoheritage and climbing activities is not only purely empirical, but also offers some important methodological developments, including those relevant to assessment issues. Three main works with general methodological proposals are those by Bollati et al. [102], Marrosu and Balvis [113], and Panizza and Mennella [116]. Their critical consideration and comparison are provided below.

Bollati et al. [102] proposed an assessment algorithm for climbing sites in regard to geoheritage, geotourism, and geoeducation. The three steps of this algorithm are as follows. First, the available information (e.g., climbing guides) is used to find climbing sites, the geological context of which is subsequently characterized. Second, these sites are assessed with some macrocriteria (the term of the noted specialists), including primary accessibility, rock cliff quality, presence of evident and active hazards, and human intervention on the cliff. Third, geodiversity sites are evaluated quantitatively. Scientific, additional, and usage values are established via scoring by numerous criteria and subsequent recalculation on the basis of the original formulae. This methodology is very sensible, although it remains intuitive and somewhat limited. For instance, it emphasizes geomorphology and pays attention to only geomorphological and geological processes, not objects; geodiversity is restricted to the number of landforms and lithologies. It is proposed to distinguish between accommodation facilities on the basis of their remoteness from the site, but different distances matter depending on how tourists reach the latter (remoteness of $5 \mathrm{~km}$ has a different meaning for visitors arriving by car and visitors arriving afoot). The application of this methodology for assessment purposes would become challenging in situations different from those considered by the authors, and would also be highly subjective (some criteria need modification or clarification).

Marrosu and Balvis [113] tried to offer a comprehensive approach for assessment of the environmental impact of climbing activities with special emphasis on geoheritage. They suggested scoring according to several indicators that were attributed to five major criteria, namely, degree of exploitation, modality of exploitation, protection value, ecological value, and cultural historical value. Total scores signify the anthropogenic pressure and are thought to be basis for managerial recommendations and local planning. Although these criteria and the relevant indicators are detailed, and this assessment system is well thought out, some questions remain unresolved. For instance, rocks of different lithology have different vulnerability to human pressure. Although granites or gneisses are very hard, and difficult to destroy, even in the case of over-crowding, the situation is different for limestones or shales. The cultural historical values are sensible, but these can be established in the only Italian reality because the relevant indicators are linked to the information from the Italian Alpine Club. It should be also added that the specific features of geoheritage itself are not considered. Apparently, geodiversity, degree of uniqueness, and aesthetic properties of geological and geomorphological features can be also used for determination of geosite vulnerability. Generally, this assessment methodology forms a promising basis for future, universal developments, but can be used in the present state with certain limitations and cautions.

Finally, Panizza and Mennella [116] developed an assessment methodology for geomorphosite popular among climbers. These authors suggested account hazard factors on rock walls be taken into account, with emphasis on geotechnical parameters. For instance, rock wall orientation, rock hardness, presence of discontinuities, natural friction angle, permeability, and some other parameters were judged to be important. Undoubtedly, this methodology is highly specific, but, nonetheless, it is comprehensive in regard to possible risks to climbers. Notably, it does not address geoheritage valuation.

The above-mentioned assessment methodologies differ essentially. Bollati et al. [102] focused on general assessment, Marrosu and Balvis [113] dealt with assessment of environmental risks, and Panizza and Mennella [116] addressed climbing risks. All seem to be essentially intuitive and can be applied to 
particular situations. Moreover, these methodologies are similar in regard to their basic premise, i.e., the essential importance of sites for climbers. Future methodological developments should take into account these tentative attempts, but should also consider other issues and situations. For instance, not only do geological/geomorphological, ecological, and tourism parameters have to be taken into account, but also parameters characterizing socio-economic contexts and the significance of coupled geosites and climbing sites, as well as attitudes, behavior, and preferences of climbers and geotourists. Significant attention should be paid to aesthetic properties of geological objects and whole landscapes. Nonetheless, the noted assessment methodologies highlight yet another direction for further research because their authors themselves consider application to planning. In regard to this issue, Marrosu and Balvis [113] demonstrated how their approach can be used for area zoning, which allows the well-balanced use of sites to be planned.

\section{Discussion}

\subsection{Research Gaps}

The present review of the sources dealing with geoheritage in relation to climbing activities implies this research direction brings interesting, diverse, and important (theoretically and practically) results. Furthermore, the reviewed topic has persisted for about a decade. However, two serious biases are found. First, the number of published works remains restricted (Figure 1), which means that each principal topic is covered by a limited number of publications (Table 2). One would expect more frequent analysis of geoheritage and climbing due to their natural concurrence. Second, there is a large geographical bias because of the limited global dispersal of the reviewed research (Figure 2). The information is absent from many mountainous domains of the world, including the Andes, the Himalaya, and many other mountain chains of the Americas, Africa, Australia, and even Europe. It is impossible to believe that their rich geoheritage occurs where climbers are absent, and vice versa.

The critical consideration of the research on geoheritage and climbing activities allows the identification of some important research gaps to be filled by further investigation. First, the majority of the reviewed sources reflect a "positivist" view, which generally considers geoconservation/geotourism and climbing as mutually important activities. Environmental concerns and safety concerns also exist, but these research lines are less important. Apparently, too little is still known about geoheritage damage and loss at climbing sites, as well as about the challenges for climbers linked to geoheritage establishment. Second, there is only weak evidence of the climbers' interest in geoheritage, geoeducation, and geoconservation. Similarly, it is unclear how many geotourists are ready for a climbing experience, even if minimal and the simplest. In other words, any successful relationship between geoheritage and climbing activities requires curiosity and education demand from climbers, and physical training and certain risk-taking by geotourists. Third, the available research does not provide evidence of how "ordinary" geotourists and professional climbers may tolerate each other. One may hypothesize that the concentration of climbers will make a given geosite less attractive to geotourists due to apparent difficulty of routes, and crowding by geotourists will distract climbers (it would be difficult to feel like an outstanding peak conqueror while surrounded by dozens of "just tourists"). Fourth, more attention should be paid to geoparks. These establishments serve geotourists (sensu stricto) and many other types of tourists, and these may be essential for joint development of geoheritage management, geotourism, and climbing activities. Although some reviewed sources focus on geoparks (Table 1), the wide international networks of the latter $[7,23,24,29]$ offer more opportunities for analysis of the above-mentioned joint development. Fifth, the geographical focus of the reviewed research direction is centered on continents or big islands (Table 1, Figure 2). However, the example of the Azores [118] indicates that small islands can be important geoheritage localities offering various opportunities for climbing activities. It should be also noted that many oceanic islands are often stressed by tsunamis, extreme storms, and super-typhoons, with megaclasts a signature feature (e.g., see review in [80]). Megaclasts are essentially geoheritage objects (due to the uniqueness of their size 
and origin), and these are ideal to bouldering; moreover, bouldering, when developed earlier, can be helpful to geoscientists for finding these unique geological features [80]. Undoubtedly, the relevant research needs intensification.

In addition to the above-mentioned research gaps, two other issues should be noted. First, the assessment methodologies are few, different (also in focus), and require significant development. Undoubtedly, further developments should be less intuitive and more universal. Second, the reviewed sources do not provide much information about the aesthetic factor and the visual damage of geosites and geomorphosites. Moreover, it is highly possible that geotourists and climbers have different senses of beauty, and their scenic preferences would also differ. Both issues need to be addressed in the course of future investigation.

\subsection{Sustainability Issues}

Sustainability and sustainable development are highly complex ideas with diverse applications. Generally, these have environmental [120-124], socio-economic (especially in regard to income, job opportunities, and well-being of local communities) [125-129], educational [130-134], and organizational (levels of firms and industries like tourism) [135-139] aspects. A share of 58\% of the sources reviewed for the purposes of the present study deal with sustainability. Generally, this means that the relationships between geoheritage and climbing activities are analyzed in the frame of sustainability, and the possible contribution of this pair to sustainable development is understood and proven by the decade of research. A total of nine sustainability-related topics were established, and these were analyzed in different general contexts (Table 3). The emphasis was made on environmental sustainability, but a wide circle of problems was considered. These topics can be understood as the main meanings of sustainability in the research on geoheritage and climbing activities.

Table 3. Sustainability-related topics of the reviewed literature.

\begin{tabular}{ccc}
\hline Topic & General Context & Sources \\
\hline $\begin{array}{c}\text { S1. Sustainable tourism } \\
\text { S2. Ecological education and contribution to } \\
\text { environmental responsibility }\end{array}$ & Industrial sustainability & {$[96,99,106,118]$} \\
\hline S3. Geoethics & Environmental sustainability & {$[101,108,114,119]$} \\
\hline S4. Nature-oriented planning & Environmental sustainability & {$[97]$} \\
\hline S5. Recreational use of abandoned mining sites & Environmental sustainability & {$[98]$} \\
\hline S6. Absence of challenges to sustainability & Environmental sustainability & {$[107]$} \\
\hline S7. Local communities' income & Socio-economic sustainability & {$[108,111]$} \\
\hline S8. Struggling with social problems & Socio-economic sustainability & {$[111]$} \\
\hline $\begin{array}{c}\text { S9. Balancing conservation, climbing, and } \\
\text { economic profit }\end{array}$ & General sustainability & {$[113]$} \\
\hline
\end{tabular}

The sustainability-related topics (Table 3) and the principal topics of the reviewed literature (Table 2) form the basis for the general characteristics of the contribution of the combination of geoheritage management and climbing to local sustainable development (Figure 3).

Two notes regarding the conceptual scheme should be made. First, climbers may provide sufficient information about the location of potentially unique geological and geomorphological features; moreover, they can support geoconservationists with geoheritage descriptions because their training allows access to high cliffs or deep canyons. If so, climbing stimulates environmental sustainability through better awareness of geoheritage to be conserved subsequently. Second, coupling geotourism and climbing changes aesthetic properties of geological landscapes. In fact, scenic beauty and aesthetic preferences of tourists depend on different parameters [140-146]. On one hand, 
establishment of geoheritage increases uniqueness of the site, making it more beautiful in the eyes of visitors [144]. On the other hand, too many tourists (climbers coupled with geotourists) or infrastructure over-development (linked to geoheritage management and/or climbers needs) makes sites less natural, which questions scenic beauty [144]. These and the other sustainability-related issues need to be better addressed in the research on geoheritage and climbing activities. As a starting point, this research should become less focused on geoheritage and climbing opportunities and more focused on site visitors, their attitudes, behavior, and perceptions.

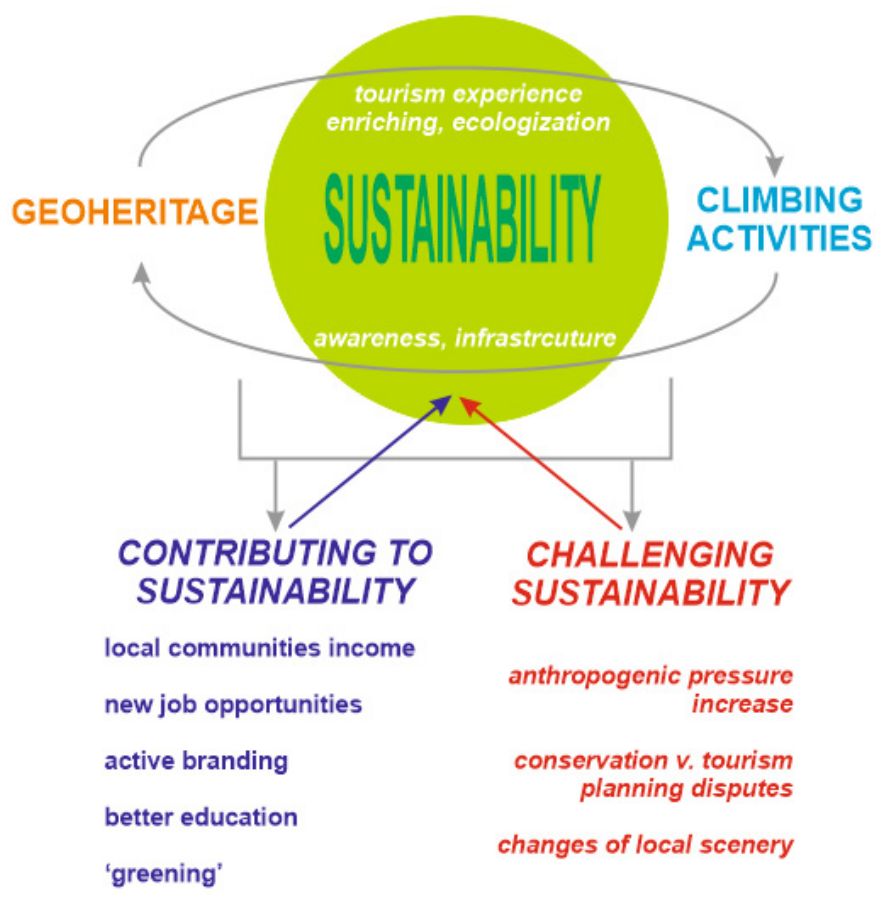

Figure 3. Relationship of geoheritage management (including geotourism) and climbing activities to sustainability.

\subsection{The World Highest Peaks: An Important Research Direction}

The world's highest peaks, which include mountains higher than $8000 \mathrm{~m}$ and the highest mountains of the continents, should be of special concern in the research on geoheritage and climbing activities (surprisingly, this is not so) because of three circumstances. First, conquering at least one of them is the dream of each true climber. Second, these mountains are by definition geomorphosites of global rank as their uniqueness results from their extraordinary height. Third, presumably some, if not many, of these mountains boast geoheritage features. Geology of the highest peaks of the world is a new topic, and a contribution to it was made by Searle [147], who summarized the knowledge of the geology of the highest peaks of the Himalaya and south Tibet.

Qomolangma (Everest) is the highest mountain of the world (8850 m), which makes it a world-class geomorphosite. Its summit rocks belong to the Lower Chiatsun Group (Ordovician) and include crinoid-bearing limestones, cyanobacterian mounds, and shales [147]. From these, the thrombolite bed (cyanobacterian mound), which marks a specific palaeoenvironment and palaeoecosystem, is of evident heritage value (unique features of this kind constitute the palaeogeographical type of geoheritage $[148,149])$. However, only professional climbing skills allow direct access to this geoheritage [150]. Nonetheless, active mountaineering raises some environmental and social problems and concerns there [72,151]. The Sagarmatha (Mount Everest) National Park of Nepal is recognized as a World Heritage Site, and is of recognizable economic value that contributes to the local sustainable development [152]. Interestingly, visitor perception of this park depends on the visitors' education level and requires professional interpretation [153], which is strongly related to some findings of the present 
review. In particular, the development of geotourism, which is linked to education and interpretation by definition $[4,154,155]$, is able to strengthen the educational component of the tourism activities in the vicinities of Qomolangma. Establishment of viewpoint geosites offering panoramic views of geoheritage from a certain distance $[156,157]$ would make the geoheritage of this peak accessible to less-trained visitors.

The situation is comparable in the case of Kilimanjaro, which is the highest mountain in Africa (5895 m). Its geomorphosite status is undisputable due to the height, and its value as a geosite is manifested by the notable geologic characteristics of this polyphase Late Quaternary volcano [158-161]. Although climbing this mountain is easier than climbing the Himalayan peaks, it is also related to certain risks and limitations [162,163], which anchors geoheritage access in the mountaineering community. Additionally, despite quite positive perceptions of tourism activities on Kilimanjaro [164], the negative environmental effects (particularly, solid waste accumulation) are also evident [165], and these challenge the local sustainability.

Both examples demonstrate that the world's highest peaks are of crucial importance for the research on geoheritage and climbing activities. This is linked to their limited accessibility, demand for education/interpretation, and local sustainable development. However, this direction of research is yet to evolve.

\section{Conclusions}

The present review of the scientific publications focusing on geoheritage and climbing activities permits five general conclusions to be made. First, the studied research direction is weak in regard to its publishing activity and geographical scope, but brings interesting and thematically diverse results. Second, the reviewed literature focuses on geoconservation, geoeducation, the tourism industry, and tourism opportunities. Third, several methodologies have been proposed for site assessment, but these differ substantially and can only be applied to certain situations. Fourth, there are significant gaps in the research of geoheritage and climbing activities; in particular, more attention should be paid to attitudes, behavior, and perceptions of geotourists and climbers, as well as to aesthetic issues. Fifth, the available literature permits conceptualization of how the related geoheritage and climbing activities are linked to various sustainability issues.

The main limitation of this study is the consideration of only the published scientific articles. Further investigations should examine the relationships between geoheritage management and climbing activities in the world experience; in particular, the opinions of managers and visitors require examination and conceptualization. The promising findings and revealed research gaps specified in this review highlight the main perspectives for further research. Special attention should be paid to heritage value and activities in areas where the world's highest peaks are situated. Furthermore, there is yet another topic that requires further investigation, namely, the relationship between specific geological and geomorphological features constituting geoheritage and climbing activities and techniques (earlier, Gray [6] demonstrated the importance of tracing similar relationships, although in regard to other geoheritage issues). In fact, landscapes with certain unique rocks may be more valuable to climbers, and such a relationship leads to the intersection between the needs of geoconservation, geotourism, and climbing.

Author Contributions: Conceptualization, D.A.R. and V.A.E.; methodology, D.A.R.; investigation, D.A.R.; writing-original draft preparation, D.A.R. and V.A.E.; writing-review and editing, D.A.R. All authors have read and agreed to the published version of the manuscript.

Funding: This research received no external funding.

Acknowledgments: The authors gratefully thank the journal editors and the reviewers for valuable recommendations and support.

Conflicts of Interest: The authors declare no conflict of interest. 


\section{References}

1. Bentivenga, M.; Cavalcante, F.; Mastronuzzi, G.; Palladino, G.; Prosser, G. Geoheritage: The Foundation for Sustainable Geotourism. Geoheritage 2019, 11, 1367-1369. [CrossRef]

2. Brilha, J.; Gray, M.; Pereira, D.I.; Pereira, P. Geodiversity: An integrative review as a contribution to the sustainable management of the whole of nature. Environ. Sci. Policy 2018, 86, 19-28. [CrossRef]

3. Brocx, M.; Semeniuk, V. The ' $8 \mathrm{Gs}$ '-a blueprint for Geoheritage, Geoconservation, Geo-education and Geotourism. Aust. J. Earth Sci. 2019, 66, 803-821. [CrossRef]

4. Dowling, R.; Newsome, D. (Eds.) Handbook of Geotourism; Edward Elgar: Cheltenham, UK, 2018.

5. Gordon, J.E. Geoheritage, geotourism and the cultural landscape: Enhancing the visitor experience and promoting geoconservation. Geosciences 2018, 8, 136. [CrossRef]

6. Gray, M. Geodiversity: Valuing and Conserving Abiotic Nature; Wiley-Blackwell: Chichester, UK, 2013.

7. Henriques, M.H.; Brilha, J. UNESCO Global Geoparks: A strategy towards global understanding and sustainability. Episodes 2017, 40, 349-355. [CrossRef]

8. Henriques, M.H.; Castro, A.R.S.F.; Félix, Y.R.; Carvalho, I.S. Promoting sustainability in a low density territory through geoheritage: Casa da Pedra case-study (Araripe Geopark, NE Brazil). Resour. Policy 2020, 67, 101684. [CrossRef]

9. Pescatore, E.; Bentivenga, M.; Giano, S.I.; Siervo, V. Geomorphosites: Versatile tools in geoheritage cultural dissemination. Geoheritage 2019, 11, 1583-1601. [CrossRef]

10. Prosser, C.D. Our rich and varied geoconservation portfolio: The foundation for the future. Proc. Geol. Assoc. 2013, 124, 568-580. [CrossRef]

11. Prosser, C.; Murphy, M.; Larwood, J. Geological Conservation: A Guide to Good Practice; English Nature: Peterborough, UK, 2006.

12. Reynard, E.; Brilha, J. (Eds.) Geoheritage: Assessment, Protection, and Management; Elsevier: Amsterdam, The Netherlands, 2018.

13. Štrba, L.; Kolackovská, J.; Kudelas, D.; Kršák, B.; Sidor, C. Geoheritage and geotourism contribution to tourism development in protected areas of Slovakia-theoretical considerations. Sustainability 2020, 12, 2979. [CrossRef]

14. Thomas, M.F. New keywords in the geosciences-Some conceptual and scientific issues. Rev. Inst. Geol. Sao Paolo 2016, 37, 1-12. [CrossRef]

15. Wimbledon, W.A.P.; Smith-Meyer, S. (Eds.) Geoheritage in Europe and Its Conservation; ProGEO: Oslo, Norway, 2012.

16. Hose, T.A. 3G's for modern geotourism. Geoheritage 2012, 4, 7-24. [CrossRef]

17. Olafsdottir, R.; Tverijonaite, E. Geotourism: A systematic literature review. Geosciences 2018, 8, 234. [CrossRef]

18. Chakrabarty, P.; Mandal, R. Geotourism mapping for sustainability: A basin oriented approach. Geoj. Tour. Geosites 2018, 21, 174-185.

19. Jorgenson, J.; Nickerson, N. Geotourism and Sustainability as a Business Mindset. J. Hosp. Mark. Manag. 2016, 25, 270-290. [CrossRef]

20. Marlina, E.; Herawan, T. Geotourism concept development in the basis of environment sustainability, socioculture, and natural science wealth: A case study in Indonesia. J. Environ. Manag. Tour. 2020, 11, 145-158. [CrossRef]

21. Pásková, M. Can indigenous knowledge contribute to the sustainability management of the aspiring rio coco geopark, Nicaragua? Geosciences 2018, 8, 277. [CrossRef]

22. Štrba, L.; Kršák, B.; Sidor, C. Some comments to geosite assessment, visitors, and geotourism sustainability. Sustainability 2018, 10, 2589. [CrossRef]

23. Catana, M.M.; Brilha, J.B. The role of UNESCO global geoparks in promoting geosciences education for sustainability. Geoheritage 2020, 12, 1. [CrossRef]

24. Ding, H.; Li, X.; Dai, J.; Xue, Y. Spatial distribution of UNESCO global geoparks in China and its influencing factors. Int. J. Des. Nat. Ecodynamics 2020, 15, 47-55. [CrossRef]

25. Eder, F.W.; Patzak, M. Geoparks-geological attractions: A tool for public education, recreation and sustainable economic development. Episodes 2004, 27, 162-164. [CrossRef]

26. Farsani, N.T.; Coelho, C.; Costa, C. Geotourism and geoparks as novel strategies for socio-economic development in rural areas. Int. J. Tour. Res. 2011, 13, 68-81. [CrossRef] 
27. Mc Keever, P.J.; Zouros, N. Geoparks: Celebrating earth heritage, sustaining local communities. Episodes 2005, 28, 274-278. [CrossRef] [PubMed]

28. Rosado-González, E.M.; Sá, A.A.; Palacio-Prieto, J.L. UNESCO Global Geoparks in Latin America and the Caribbean, and their contribution to agenda 2030 sustainable development goals. Geoheritage 2020, 12, 36. [CrossRef]

29. Zouros, N. The European Geoparks network. Episodes 2004, 27, 165-171. [CrossRef]

30. Habibi, T.; Ponedelnik, A.A.; Yashalova, N.N.; Ruban, D.A. Urban geoheritage complexity: Evidence of a unique natural resource from Shiraz city in Iran. Resour. Policy 2018, 59, 85-94. [CrossRef]

31. Ruban, D.A. Quantification of geodiversity and its loss. Proc. Geol. Assoc. 2010, 121, 326-333. [CrossRef]

32. Reynard, E.; Coratza, P.; Giusti, C. Geomorphosites and Geotourism. Geoheritage 2011, 3, 129-130. [CrossRef]

33. Brocx, M.; Semeniuk, V. Geodiversity and the '8Gs': A response to Gray \& Gordon (2020). Aust. J. Earth Sci. 2020, 67, 445-451.

34. Gonçalves, J.; Mansur, K.; Santos, D.; Henriques, R.; Pereira, P. A Discussion on the quantification and classification of Geodiversity indices based on GIS methodological tests. Geoheritage 2020, 12, 38. [CrossRef]

35. Gray, M.; Gordon, J.E. Geodiversity and the '8Gs': A response to Brocx \& Semeniuk (2019). Aust. J. Earth Sci. 2020, 67, 437-444.

36. Knight, J. Evaluating geological heritage: Correspondence on Ruban, D.A. 'Quantification of geodiversity and its loss' (PGA, 2010, 121(3): 326-333). Proc. Geol. Assoc. 2011, 122, 508-510. [CrossRef]

37. Read, Q.D.; Zarnetske, P.L.; Record, S.; Dahlin, K.M.; Costanza, J.K.; Finley, A.O.; Gaddis, K.D.; Grady, J.M.; Hobi, M.L.; Latimer, A.M.; et al. Beyond counts and averages: Relating geodiversity to dimensions of biodiversity. Glob. Ecol. Biogeogr. 2020, 29, 696-710. [CrossRef]

38. Ruban, D.A. How diverse should be geodiversity? Reply to Knight "Evaluating geological heritage" (Proc. Geol. Assoc. (2011)). Proc. Geol. Assoc. 2011, 122, 511-513. [CrossRef]

39. Thomas, M.F. A geomorphological approach to geodiversity-Its a pplications to geoconservation and geotourism. Quaest. Geogr. 2012, 31, 81-89.

40. Chrobak, A.; Witkowski, K.; Szmanda, J. Assessment of the educational values of geomorphosites based on the expert method, case study: The Bialka and Skawa rivers, the Polish Carpathians. Quaest. Geogr. 2020, 39, 45-57. [CrossRef]

41. Santos, D.S.; Reynard, E.; Mansur, K.L.; Seoane, J.C.S. The specificities of Geomorphosites and their influence on assessment procedures: A methodological comparison. Geoheritage 2019, 11, 2045-2064. [CrossRef]

42. Seifert, L.; Wolf, P.; Schweizer, A. (Eds.) The Science of Climbing and Mountaineering; Routledge: London, UK, 2018.

43. Giles, L.V.; Rhodes, E.C.; Taunton, J.E. The physiology of rock climbing. Sports Med. 2006, 36, 529-545. [CrossRef]

44. MacKenzie, R.; Monaghan, L.; Masson, R.A.; Werner, A.K.; Caprez, T.S.; Johnston, L.; Kemi, O.J. Physical and physiological determinants of rock climbing. Int. J. Sports Physiol. Perform. 2020, 15, 168-179. [CrossRef]

45. Siegel, S.R.; Fryer, S.M. Rock climbing for promoting physical activity in youth. Am. J. Lifestyle Med. 2017, 11, 243-251. [CrossRef]

46. Delle Fave, A.; Bassi, M.; Massimini, F. Quality of experience and risk perception in high-altitude rock climbing. J. Appl. Sport Psychol. 2003, 15, 82-98. [CrossRef]

47. Langseth, T.; Salvesen, $\varnothing$. Rock climbing, risk, and recognition. Front. Psychol. 2018, 9, 1793. [CrossRef]

48. Llewellyn, D.J.; Sanchez, X. Individual differences and risk taking in rock climbing. Psychol. Sport Exerc. 2008, 9, 413-426. [CrossRef]

49. Llewellyn, D.J.; Sanchez, X.; Asghar, A.; Jones, G. Self-efficacy, risk taking and performance in rock climbing. Personal. Individ. Differ. 2008, 45, 75-81. [CrossRef]

50. Kulczycki, C. Place meanings and rock climbing in outdoor settings. J. Outdoor Recreat. Tour. 2014, 7-8, 8-15. [CrossRef]

51. Clark, P.; Hessl, A. The effects of rock climbing on cliff-face vegetation. Appl. Veg. Sci. 2015, 18, 705-715. [CrossRef]

52. Covy, N.; Benedict, L.; Keeley, W.H. Rock climbing activity and physical habitat attributes impact avian community diversity in cliff environments. PLoS ONE 2019, 14, e0209557. [CrossRef]

53. Dagan, D.T.; Sharp, R.L.; Walendziak, N. Longitudinal variation in rock climbing impacts in the Red River gorge area of the Daniel Boone national forest. J. For. 2019, 117, 9-12. [CrossRef] 
54. Holzschuh, A. Does rock climbing threaten cliff biodiversity-A critical review. Biol. Conserv. 2016, 204, 153-162. [CrossRef]

55. Lorite, J.; Serrano, F.; Lorenzo, A.; Cañadas, E.M.; Ballesteros, M.; Peñas, J. Rock climbing alters plant species composition, cover, and richness in Mediterranean limestone cliffs. PLoS ONE 2017, 12, e0182414. [CrossRef]

56. Musa, G.; Higham, J.; Thompson-Carr, A. (Eds.) Mountaineering Tourism; Routledge: London, UK, 2015.

57. Apollo, M. The true accessibility of mountaineering: The case of the High Himalaya. J. Outdoor Recreat. Tour. 2017, 17, 29-43. [CrossRef]

58. Bainbridge, S. Romantic writers and mountaineering. Romanticism 2012, 18, 1-15. [CrossRef]

59. Lenglet, M.; Rozin, P. Institutional work in high-altitude mountaineering: Rope-fixing, the 'Everest brawl' and changes in sherpa actorhood. Res. Sociol. Organ. 2019, 58, 229-249.

60. Hunt, R. Historical geography, climbing and mountaineering: Route setting for an inclusive future. Geogr. Compass 2019, 13, e12423. [CrossRef]

61. Klein, K.L. A vertical world: The eastern Alps and modern mountaineering. J. Hist. Sociol. 2011, 24, 519-548. [CrossRef]

62. Allen-Collinson, J.; Crust, L.; Swann, C. Embodiment in high-altitude mountaineering: Sensing and working with the weather. Body Soc. 2019, 25, 90-115. [CrossRef]

63. Bahaeloo-Horeh, S.; Assari, S. Students experience self-esteem improvement during mountaineering. Wilderness Environ. Med. 2008, 19, 181-185. [CrossRef] [PubMed]

64. Bott, E. Big mountain, big name: Globalised relations of risk in Himalayan mountaineering. J. Tour. Cult. Chang. 2009, 7, 287-301. [CrossRef]

65. Clarke, C. Endeavour, altitude and risk: Reflections on a lifetime of mountaineering and exploration. J. Med. Biogr. 2012, 20, 130-135. [CrossRef]

66. Crust, L. Personality and mountaineering: A critical review and directions for future research. Personal. Individ. Differ. 2020, 163, 110073. [CrossRef]

67. Duits, R. Mountaineering, Myth and the Meaning of Life: Psychoanalysing alpinism. J. Philos. Sport 2020, 47, 33-48. [CrossRef]

68. Faullant, R.; Matzler, K.; Mooradian, T.A. Personality, basic emotions, and satisfaction: Primary emotions in the mountaineering experience. Tour. Manag. 2011, 32, 1423-1430. [CrossRef]

69. Gugglberger, M. Wanda Rutkiewicz-crossing boundaries in women's mountaineering. Sport Soc. 2017, 20, 1059-1076. [CrossRef]

70. Loewenstein, G. Because it is there: The challenge of mountaineering... for utility theory. Kyklos 1999, 52, 315-343. [CrossRef]

71. Pomfret, G. Mountaineering adventure tourists: A conceptual framework for research. Tour. Manag. 2006, 27, 113-123. [CrossRef]

72. Cullen, R. Himalayan mountaineering expedition garbage. Environ. Conserv. 1986, 13, 293-297. [CrossRef]

73. Purdie, H.; Kerr, T. Aoraki Mount Cook: Environmental change on an iconic mountaineering route. Mt. Res. Dev. 2018, 38, 364-379. [CrossRef]

74. Karg, N.; Dorscht, L.; Kornhuber, J.; Luttenberger, K. Bouldering psychotherapy is more effective in the treatment of depression than physical exercise alone: Results of a multicentre randomised controlled intervention study. BMC Psychiatry 2020, 20, 116. [CrossRef] [PubMed]

75. Medernach, J.P.J.; Kleinöder, H.; Lötzerich, H.H.H. Fingerboard in competitive bouldering: Training effects on grip strength and endurance. J. Strength Cond. Res. 2015, 29, 2286-2295. [CrossRef]

76. Schwarz, L.; Dorscht, L.; Book, S.; Stelzer, E.-M.; Kornhuber, J.; Luttenberger, K. Long-term effects of bouldering psychotherapy on depression: Benefits can be maintained across a 12-month follow-up. Heliyon 2019, 5, e02929. [CrossRef]

77. Ness, S.A. Bouldering in Yosemite: Emergent signs of place and landscape. Am. Anthropol. 2011, 113, 71-87. [CrossRef]

78. Tessler, M.; Clark, T.A. The impact of bouldering on rock-associated vegetation. Biol. Conserv. 2016, 204, 426-433. [CrossRef]

79. Van der Merwe, J.H.; Joubert, U. Managing environmental impact of bouldering as a niche outdoor-climbing activity. South Afr. J. Res. Sport Phys. Educ. Recreat. 2014, 36, 229-251.

80. Ruban, D.A. Finding coastal Megaclast deposits: A virtual perspective. J. Mar. Sci. Eng. 2020, 8, 164. [CrossRef] 
81. Hardiman, N.; Burgin, S. Canyoning adventure recreation in the Blue Mountains World Heritage Area (Australia): The canyoners and canyoning trends over the last decade. Tour. Manag. 2011, 32, 1324-1331. [CrossRef]

82. Perrin, C.; Mounet, J. L'insertion de l'offre de canyoning dans l'industrie touristique: Une étude comparative entre le massif des Bauges et le Vercors. Loisir Soc. 2004, 27, 143-172. [CrossRef]

83. Perrin, C.; Mounet, J.-P. The sporting organization of canyoneering at one location: The Furon canyon. Sci. Mot. 2006, 57, 79-103.

84. Suchet, A.; Jorand, D. Les usagers des parcours naturels de canyoning et de la structure artificielle canyoning park (France): Une approche socio-culturelle. Loisir Soc. 2007, 30, 417-441. [CrossRef]

85. Ballesteros Peña, S. Evaluation of adherence to safety practices in the practice of canyoning in Sierra de Guara (Huesca, Spain). Arch. Med. Deporte 2013, 30, 91-95.

86. Brandão, A.; Marques, A.N.A.; Pereira, J.; Coelho, E.; Quaresma, L. Development of a tool to analyze risk perception in canyoning using a delphi technique. J. Phys. Educ. Sport 2018, 18, 1028-1034.

87. Magadan-Díaz, M.; Rivas-García, J. Sustainable tourism in mountain protected areas of asturias: An analysis from tourists' perceptions and profiles. Sustain. Dev. Mt. Territ. 2019, 11, 459-474. [CrossRef]

88. Maikhuri, R.K.; Rana, U.; Rao, K.S.; Nautiyal, S.; Saxena, K.G. Promoting ecotourism in the buffer zone areas of Nanda Devi Biosphere Reserve: An option to resolve people-policy conflict. Int. J. Sustain. Dev. World Ecol. 2000, 7, 333-342. [CrossRef]

89. Peršolja, B. Mountaineering, not hillwalking. Geogr. Obz. 2017, 64, 4-9.

90. Erhard, A. Mt. Kenya-Observations of mountaineering tourism and its economic benefits. Erde 2000, 131, 161-177.

91. Johnston, B.R.; Edwards, T. The commodification of mountaineering. Ann. Tour. Res. 1994, 21, 459-478. [CrossRef]

92. Steinicke, E.; Neuburger, M. The impact of community-based afro-alpine tourism on regional development. Mountain Res. Dev. 2012, 32, 420-430. [CrossRef]

93. Fernandez, K.V. Critically reviewing literature: A tutorial for new researchers. Australas. Mark. J. 2019, 27, 187-196. [CrossRef]

94. Snyder, H. Literature review as a research methodology: An overview and guidelines. J. Bus. Res. 2019, 104, 333-339. [CrossRef]

95. Sovacool, B.K.; Axsen, J.; Sorrell, S. Promoting novelty, rigor, and style in energy social science: Towards codes of practice for appropriate methods and research design. Energy Res. Soc. Sci. 2018, 45, $12-42$. [CrossRef]

96. Aldighieri, B.; Testa, B.; Bertini, A. 3D exploration of the San Lucano valley: Virtual geo-routes for everyone who would like to understand the landscape of the dolomites. Geoheritage 2016, 8, 77-90. [CrossRef]

97. Alexandrowicz, $Z$. The impact of rock climbing on the micro-relief of sandstone surfaces: The case study of the Carpathian tors. Episodes 2017, 40, 63-69. [CrossRef]

98. Arjana, I.W.B.; Ernawati, N.M.; Astawa, I.K. Tourist attractions of Batur geotourism, Bali. J. Environ. Manag. Tour. 2019, 10, 1399-1404.

99. Ates, H.Ç.; Ates, Y. Geotourism and rural tourism synergy for sustainable development—Marçik valley case-Tunceli, Turkey. Geoheritage 2019, 11, 207-215. [CrossRef]

100. Baczynska, E.; Lorenc, M.W.; Kazmierczak, U. The landscape attractiveness of abandoned quarries. Geoheritage 2018, 10, 271-285. [CrossRef]

101. Bollati, I.; Coratza, P.; Panizza, V.; Pelfini, M. Lithological and structural control on Italian mountain geoheritage: Opportunities for tourism, outdoor and educational activities. Quaest. Geogr. 2018, 37, 53-73. [CrossRef]

102. Bollati, I.; Fossati, M.; Zanoletti, E.; Zucali, M.; Magagna, A.; Pelfini, M. A methodological proposal for the assessment of cliffs equipped for climbing as a component of geoheritage and tools for earth science education: The case of the Verbano-Cusio-Ossola (Western Italian Alps). J. Virtual Explor. 2016, 49, 1-23.

103. Bollati, I.M.; Gatti, C.; Pelfini, M.P.; Speciale, L.; Maffeo, L.; Pelfini, M. Climbing walls in Earth Sciences education: An interdisciplinary approach for the secondary school (1st level). Rend. Online Soc. Geol. Ital. 2018, 44, 134-142. [CrossRef] 
104. Bollati, I.; Zucali, M.; Giovenco, C.; Pelfini, M. Geoheritage and sport climbing activities: Using the Montestrutto cliff (Austroalpine domain, Western Alps) as an example of scientific and educational representativeness. Ital. J. Geosci. 2014, 133, 187-199. [CrossRef]

105. Borgatti, L.; Tosatti, G. Slope instability processes affecting the Pietra di Bismantova Geosite (Northern Apennines, Italy). Geoheritage 2010, 2, 155-168. [CrossRef]

106. Brandolini, P.; Faccini, F.; Robbiano, A.; Bulgarelli, F. Geomorphology and cultural heritage of the Ponci Valley (Finalese karstic area, Ligurian Alps). Geogr. Fis. E Din. Quat. 2011, 34, 65-74.

107. Chaloupsky, D. Rock climbing in Czech Paradise: Historical development of the frequency of traditional ascents at selected sandstone towers. J. Hum. Sport Exerc. 2014, 9, 276-283. [CrossRef]

108. Elvien Kristian, V.A.; Ridho, A.; Alffi, F.D. Geotourism of Batu Dinding kilo Tiga, Amurang District, South Minahasa Regency, North Sulawesi-Indonesia. OP Conf. Ser. Earth Environ. Sci. 2018, 132, 012030. [CrossRef]

109. Flaviu, C.H.; Barna, S. Touristic capitalization of the geomorphic karsts in the Haghimas Mountains. In Proceedings of the 14th International Multidisciplinary Scientific GeoConference Surveying Geology and Mining Ecology Management (SGEM), Albena, Bulgaria, 17-26 June 2014; Volume 3, pp. 1017-1022.

110. García-Rodríguez, M.; Fernández-Escalante, E. Geo-Climbing and environmental education: The Value of la Pedriza granite massif in the Sierra de Guadarrama National Park, Spain. Geoheritage 2017, 9, 141-151. [CrossRef]

111. Güney, Y. The Geomorphosite potential of the badlands around Küpyar, Manisa, Turkey. Geoheritage 2020, 12, 21. [CrossRef]

112. Kedrowski, J.J. Determining the relative annual mountain climbing frequency on Colorado's 14,000 -foot peaks. Mt. Res. Dev. 2009, 29, 82-92. [CrossRef]

113. Marrosu, G.M.; Balvis, T. Environmental impact assessment in climbing activities: A new method to develop a sustainable tourism in geological and nature reserves. Geoheritage 2020, 12, 11. [CrossRef]

114. Nevistic, Z.; Špoljaric, D. Web GIS in mountaineering in Croatia. GeoScape 2019, 13, 114-124. [CrossRef]

115. Ortega-Becerril, J.A.; Jorge-Coronado, A.; Garzón, G.; Wohl, E. Sobrarbe Geopark: An example of highly diverse bedrock rivers. Geoheritage 2017, 9, 533-548. [CrossRef]

116. Panizza, V.; Mennella, M. Assessing geomorphosites used for rock climbing. The example of Monteleone Rocca Doria (Sardinia, Italy). Geogr. Helv. 2007, 62, 181-191. [CrossRef]

117. Pat, G. By the way. Taiwan Rev. 2007, 57, 26-31.

118. Queiroz, R.E.; Guerreiro, J.; Ventura, M.A. Demand of the tourists visiting protected areas in small oceanic islands: The Azores case-study (Portugal). Environ. Dev. Sustain. 2014, 16, 1119-1135. [CrossRef]

119. Russ, B.R.; Nolasco, M.C. Revealing geodiversity through environmental education: Perceptions of students about the manga do Céu Geosite. Anu. Do Inst. Geocienc. 2012, 35, 271-280.

120. Bekun, F.V.; Alola, A.A.; Sarkodie, S.A. Toward a sustainable environment: Nexus between $\mathrm{CO}_{2}$ emissions, resource rent, renewable and nonrenewable energy in 16-EU countries. Sci. Total Environ. 2019, 657, 1023-1029. [CrossRef] [PubMed]

121. Giddings, B.; Hopwood, B.; O’Brien, G. Environment, economy and society: Fitting them together into sustainable development. Sustain. Dev. 2002, 10, 187-196. [CrossRef]

122. Liu, X.; Xu, W.; Sha, Z.; Zhang, Y.; Wen, Z.; Wang, J.; Zhang, F.; Goulding, K. A green eco-environment for sustainable development: Framework and action. Front. Agric. Sci. Eng. 2020, 7, 9297. [CrossRef]

123. Mikulcic, H.; Baleta, J.; Klemeš, J.J. Sustainability through combined development of energy, water and environment systems. J. Clean. Prod. 2020, 251, 119727. [CrossRef]

124. Omer, A.M. Energy, environment and sustainable development. Renew. Sustain. Energy Rev. 2008, 12, 2265-2300. [CrossRef]

125. Black, W.R. Socio-economic barriers to sustainable transport. J. Transp. Geogr. 2000, 8, 141-147. [CrossRef]

126. Bran, F.; Bodislav, D.-A.; Radulescu, C.V.; Ioan, I. Corporate governance intervention for a sustainable socio-economic model. Rev. Cercet. Si Interv. Soc. 2014, 46, 216-226.

127. Hobson, J.; Lynch, K.; Roberts, H.; Payne, B. Community ownership of Local Assets: Conditions for sustainable success. J. Rural. Stud. 2019, 65, 116-125. [CrossRef]

128. Maliene, V.; Howe, J.; Malys, N. Sustainable communities: Affordable housing and socio-economic relations. Local Econ. 2008, 23, 267-276. [CrossRef] 
129. Papageorgiou, K.; Singh, P.K.; Papageorgiou, E.; Chudasama, H.; Bochtis, D.; Stamoulis, G. Fuzzy cognitive map-based sustainable socio-economic development planning for rural communities. Sustainability 2020, 12, 305. [CrossRef]

130. Ahmad, N.; Hoda, N.; Alahmari, F. Developing a cloud-based mobile learning adoption model to promote sustainable education. Sustainability 2020, 12, 3126. [CrossRef]

131. Barth, M.; Godemann, J.; Rieckmann, M.; Stoltenberg, U. Developing key competencies for sustainable development in higher education. Int. J. Sustain. High. Educ. 2007, 8, 416-430. [CrossRef]

132. Giesenbauer, B.; Müller-Christ, G. University 4.0: Promoting the transformation of higher education institutions toward sustainable development. Sustainability 2020, 12, 3371. [CrossRef]

133. Svanström, M.; Lozano-García, F.J.; Rowe, D. Learning outcomes for sustainable development in higher education. Int. J. Sustain. High. Educ. 2008, 9, 339-351. [CrossRef]

134. Thomas, I. Critical thinking, transformative learning, sustainable education, and problem-based learning in universities. J. Transform. Educ. 2009, 7, 245-264. [CrossRef]

135. Battilana, J.; Dorado, S. Building sustainable hybrid organizations: The case of commercial microfinance organizations. Acad. Manag. J. 2010, 53, 1419-1440. [CrossRef]

136. Hassanli, N.; Ashwell, J. The contribution of small accommodations to a sustainable tourism industry. Curr. Issues Tour. 2020, 23, 261-264. [CrossRef]

137. Jabbour, C.J.C.; Santos, F.C.A. The central role of human resource management in the search for sustainable organizations. Int. J. Hum. Resour. Manag. 2008, 19, 2133-2154. [CrossRef]

138. Pfeffer, J. Building sustainable organizations: The human factor. Acad. Manag. Perspect. 2010, $24,34-45$.

139. Pulido-Fernández, J.I.; Andrades-Caldito, L.; Sánchez-Rivero, M. Is sustainable tourism an obstacle to the economic performance of the tourism industry? Evidence from an international empirical study. J. Sustain. Tour. 2015, 23, 47-64. [CrossRef]

140. Carlson, A.A. On the possibility of quantifying scenic beauty. Landsc. Plan. 1977, 4, 131-172. [CrossRef]

141. Daniel, T.C. Whither scenic beauty? Visual landscape quality assessment in the 21st century. Landsc. Urban Plan. 2001, 54, 267-281. [CrossRef]

142. Frank, S.; Fürst, C.; Koschke, L.; Witt, A.; Makeschin, F. Assessment of landscape aesthetics-Validation of a landscape metrics-based assessment by visual estimation of the scenic beauty. Ecol. Indic. 2013, 32, $222-231$. [CrossRef]

143. Han, K.-T. Responses to six major terrestrial biomes in terms of scenic beauty, preference, and restorativeness. Environ. Behav. 2007, 39, 529-556. [CrossRef]

144. Kirillova, K.; Fu, X.; Lehto, X.; Cai, L. What makes a destination beautiful? Dimensions of tourist aesthetic judgment. Tour. Manag. 2014, 42, 282-293. [CrossRef]

145. Schirpke, U.; Tasser, E.; Tappeiner, U. Predicting scenic beauty of mountain regions. Landsc. Urban Plan. 2013, 111, 1-12. [CrossRef]

146. Williams, A.T. The concept of scenic beauty in a landscape. Coast. Res. Libr. 2019, 26, 17-41.

147. Searle, M. Colliding Continents: A Geological Exploration of the Himalaya, Karakoram, E Tibet; Oxford University Press: Oxford, UK, 2013.

148. Bruno, D.E.; Crowley, B.E.; Gutak, J.M.; Moroni, A.; Nazarenko, O.V.; Oheim, K.B.; Ruban, D.A.; Tiess, G.; Zorina, S.O. Paleogeography as geological heritage: Developing Geosite classification. Earth-Sci. Rev. 2014, 138, 300-312. [CrossRef]

149. Sallam, E.S.; Ruban, D.A. Palaeogeographical type of the geological heritage of Egypt: A new evidence. J. Afr. Earth Sci. 2017, 129, 739-750. [CrossRef]

150. Savage, D.; Chan, H.F.; Moy, N.; Schaffner, M.; Torgler, B. Personality and individual characteristics as indicators of lifetime climbing success among Everest mountaineers. Personal. Individ. Differ. 2020, 162, 110044. [CrossRef]

151. Largent, E. Is it ethical to hire Sherpas when climbing Mount Everest? BMJ 2014, 349, g5113. [CrossRef] [PubMed]

152. Baral, N.; Kaul, S.; Heinen, J.T.; Ale, S.B. Estimating the value of the World Heritage Site designation: A case study from Sagarmatha (Mount Everest) National Park, Nepal. J. Sustain. Tour. 2017, 25, 1776-1791. [CrossRef]

153. Baral, N.; Hazen, H.; Thapa, B. Visitor perceptions of World Heritage value at Sagarmatha (Mt. Everest) National Park, Nepal. J. Sustain. Tour. 2017, 25, 1494-1512. [CrossRef] 
154. Lee, J.-K.; Woo, K.S.; Lee, H.-K. Present status and future improvement directions of educational signboards at geoheritage sites in protected areas of Korea. J. Geol. Soc. Korea 2019, 55, 37-57. [CrossRef]

155. Migoń, P.; Pijet-Migoń, E. Interpreting Geoheritage at New Zealand's geothermal tourist sites-Systematic explanation versus storytelling. Geoheritage 2017, 9, 83-95. [CrossRef]

156. Migoń, P.; Pijet-Migoń, E. Viewpoint geosites-Values, conservation and management issues. Proc. Geol. Assoc. 2017, 128, 511-522. [CrossRef]

157. Mikhailenko, A.V.; Ruban, D.A. Environment of viewpoint Geosites: Evidence from the Western Caucasus. Land 2019, 8, 93. [CrossRef]

158. Nonnotte, P.; Guillou, H.; Le Gall, B.; Benoit, M.; Cotten, J.; Scaillet, S. Petrology and geochemistry of alkaline lava series, Kilimanjaro Tanzania: New constraints on petrogenetic processes. Spec. Pap. Geol. Soc. Am. 2011, $478,127-158$.

159. Downie, C.; Humphries, D.W.; Wilcockson, W.H.; Wilkinson, P. Geology of kilimanjaro. Nature 1956, 178, 828-830. [CrossRef]

160. Wilcockson, W.H. Preliminary notes on the geology of kilimanjaro. Geol. Mag. 1956, 93, 218-228. [CrossRef]

161. Wilkinson, P.; Mitchell, J.G.; Cattermole, P.J.; Downie, C. Volcanic chronology of the Meru-Kilimanjaro region, northern Tanzania. J. Geol. Soc. 1986, 143, 601-605. [CrossRef]

162. Davies, A.J.; Kalson, N.S.; Stokes, S.; Earl, M.D.; Whitehead, A.G.; Frost, H.; Tyrell-Marsh, I.; Naylor, J. Determinants of summiting success and acute mountain sickness on Mt Kilimanjaro (5895 m). Wilderness Environ. Med. 2009, 20,311-317. [CrossRef] [PubMed]

163. Karinen, H.; Peltonen, J.; Tikkanen, H. Is there a safer and more successful way to climb Kilimanjaro? The authors reply. High Alt. Med. Biol. 2009, 10, 303. [CrossRef]

164. Ngowi, R.E.; Jani, D. Residents' perception of tourism and their satisfaction: Evidence from Mount Kilimanjaro, Tanzania. Dev. South. Afr. 2018, 35, 731-742. [CrossRef]

165. Kaseva, M.E.; Moirana, J.L. Problems of solid waste management on Mount Kilimanjaro: A challenge to tourism. Waste Manag. Res. 2010, 28, 695-704. [CrossRef]

(C) 2020 by the authors. Licensee MDPI, Basel, Switzerland. This article is an open access article distributed under the terms and conditions of the Creative Commons Attribution (CC BY) license (http://creativecommons.org/licenses/by/4.0/). 